\title{
The Effect of Zirconia Material for Dental Implant to Osseointegrated Process
}

\author{
Maya Sari Dewi ${ }^{1}$, Hendri Poernomo ${ }^{2 *}$ \\ ${ }^{1}$ Conservative Department, Faculty of Dentistry, Mahasaraswati University Denpasar \\ Indonesia ${ }^{2}$ Oral Surgery Department, Faculty of Dentistry, Mahasaraswati University \\ Denpasar Indonesia \\ *Corresponding author Email: hendri_poernomo@yahoo.co.id
}

\begin{abstract}
Objective: Tooth lost is the one of mostly case in dentistry. Dental implant is the proper and fast procedure to rehabilitated full or partial edentulous ridge. Many research and clinical study said that the successful of dental implant application are depend on osseointegration which considered by anatomical of the bone structure with implant or mechanical feature of implant.

Dissucion : The composition of material and topographic surface are the important thing in osseointegration process . For many patient, Titanium give a good results, but some of patient worried because it can make a grey line in sub gingival or across the ridge which have a thin bone and soft gingival structure, So with zirconia implant hopefully that grey line doesn't appear. Both of titanium and zirconia are very strong, Titanium have a high flexibility and fracture resistence but, zirconia have a low elasticity, which can cause a micro fracture.
\end{abstract}

Conclusion : Zirconia implant have a good esthetics and looked naturally.

Key word : implant procedure, osseointegration, titanium, zirconia

\section{LATAR BELAKANG}

Kasus kehilangan gigi idealnya harus segera direstorasi, untuk mencapai kondisi normal yang baik, sehingga hasil akhir dari perawatan dapat memperbaiki kontur yang normal, kenyamanan, estetika, fungsi bicara, dan mencegah terjadinya karies. Ada beberapa cara untuk menggantikan gigi yang hilang, yaitu antara lain, dengan gigi tiruan 
lepasan, gigi tiruan cekat dan implan gigi. Perbedaan antara ketiga cara tersebut menjadi pilihan bagi pasien. ${ }^{1}$

Implan gigi memiliki bagian yang masuk ke dalam tulang sebagai pengganti akar gigi dan disebut bagian infra struktur, sedangkan bagian atasnya sebagai tempat pemasangan gigi tiruan disebut dengan bagian supra struktur. ${ }^{1,2,3}$ Implan gigi akan memberikan stabilitas yang lebih baik untuk fungsi bicara maupun fungsi penguyahan di dalam rongga mulut ${ }^{4,5}$, dan mengurangi resiko karies, mempermudah pembersihan permukaan proksimal gigi di sebelahnya dan rata-rata kesuksesan 97\% untuk 10 tahun. ${ }^{6}$ Salah satu jenis implan gigi yang paling banyak digunakan adalah tipe endoseus, karena mempunyai tingkat keberhasilan yang tinggi. Implan gigi tipe endoseus merupakan implan yang ditanam di dalam tulang alveolar dan seluruh bagian fixture-nya dirancang untuk memfiksasi endokorteks tulang atau bagian korteks dan spongiosa tulang., ${ }^{2,7}$

Rehabilitasi pasien yang tidak memiliki gigi sebagian atau sepenuhnya dengan implan gigi merupakan modalitas perawatan yang diterima secara ilmiah dan dilaporkan dengan baik. ${ }^{8}$ Bahan implan gigi dari titanium murni dan titanium alloy sejauh ini menjadi bahan pilihan dalam implan gigi dan ortopedi. ${ }^{9}$ Bahan dari titanium memiliki biokompatibilitas yang sangat baik, sifat mekanik yang menguntungkan. ${ }^{8}$

Osseointegrasi merupakan fiksasi biologis dari implan yang berhubungan langsung dengan kontak tulang pada implan (Bone Implant Contact) tanpa intervensi jaringan ikat. Bone Implant Contact dianggap sebagai indikator kunci untuk keberhasilan osseointegrasi yang mengatur keberhasilan dan kelangsungan dari implan gigi secara keseluruhan. ${ }^{10}$

Titanium memiliki warna abu-abu sehingga dapat mengganggu estetika terutama pada kondisi mukosa yang tipis dan kondisi jaringan lunak yang tidak menguntungkan atau resisi gingiva. Kondisi menjadi perhatian besar ketika akan dilakukan pemasangan implan gigi di rahang atas anterior. Selain itu, ada penelitian yang menunjukkan bahwa logam dapat menginduksi imunomodulasi dan autoimunitas yang tidak spesifik. Dijelaskan juga efek samping galvanik setelah kontak dengan saliva dan fluoride. Meskipun ada kekurangan dari titanium tetapi reaksi alergi sangat jarang dijumpai. ${ }^{8}$

Implan gigi berbasis zirkonia digolongkan ke dalam implantologi gigi sebagai alternatif dari implan berbahan titanium. Karakteristik implan gigi zirkonia memiliki biomekanik dan biokompatibilitasnya yang sangat baik, dan warnanya seperti gigi. ${ }^{11}$ 


\section{TINJAUAN PUSTAKA}

\section{Pengenalan Implan}

Selama 10 tahun terakhir estetika gigi merupakan isu penting pada implan di bidang kedokteran gigi. Teknik untuk mendapatkan perawatan implan gigi di rahang atas anterior dapat menyebabkan kegagalan hasil perawatan yang menyebabkan kerusakan kondisi klinis, dimana hanya dapat diatasi dengan pengambilan implan dan jaringan dibawahnya melalui prosedur augmentasi. Dengan seperti pertimbangan ini, sangat penting untuk menetapkan konsep klinis secara jelas parameter, estetika yang bagus pada pemasangan implan anterior rahang atas tanpa mengesampingkan stabilitas jangka panjang dari jaringan periimplan. ${ }^{6,8,9,10}$

Dalam kebanyakan kasus, permintaan utama pasien dalam mengganti gigi yang hilang untuk meningkatkan estetika. Parameter estetika untuk perawatan restorasi gigi konvensional, dapat digunakan untuk implan gigi selama perencanaan prabedah dalam membantu menentukan faktor risiko dalam kekurangan estetik. Tujuan utama pemasangan implan gigi dari segi estetika merupakan pencapaian margin gingiva yang harmonis, mempertahankan papila yang utuh, dan mempertahankan kontur alveolar crest. ${ }^{9,10}$

Sejak diperkenalkan pertama kali, implan gigi telah diterima sebagai modalitas perawatan yang dapat diprediksi, baik untuk perawatan rehabilitasi gigi yang hilang sebagian dan sepenuhnya. Keberhasilan implan gigi terutama tergantung pada osseointegrasi implan gigi ke dalam tulang. Integrasi implan gigi sangat dipengaruhi oleh sifat-sifat permukaan implan (seperti topografi dan kimia). Berbagai modifikasi permukaan telah dikembangkan untuk meningkatkan dan mempercepat penyembuhan tulang implan gigi dan untuk meningkatkan kekuatan dan ketahanan antarmuka implan tulang terhadap pemuatan fungsional jangka panjang. ${ }^{2,3,4}$

Berbagai hasil penelitian dan pengalaman klinis menyatakan bahwa kesuksesan aplikasi implan gigi tergantung pada osseointegration dengan pertimbangan utama kecocokan anatomi antara tulang dengan implan dan sifat mekanis dari implan. ${ }^{10,11,14}$ Sementara itu, proses osseointegration dipengaruhi oleh banyak faktor diantaranya lokasi anatomi, ukuran dan desain implan, prosedur pembedahan, efek beban, lingkungan biologis, umur dan jenis kelamin, dan secara khusus karakteristik permukaan implan diantaranya komposisi kimia, wettability, adanya fasa kristalin dan amorfus, kekasaran 
dan porositas. ${ }^{15,16,17,18}$ Komposisi permukaan, sifat hidrofilik dan kekasaran permukaaan merupakan parameter yang mungkin berperan dalam interaksi jaringan implan dan proses osseointegration. Tinjauan ini berfokus pada berbagai struktur permukaan yang kasar dan halus yang bertujuan untuk mempercepat proses osseointegration dari implan gigi. ${ }^{3,19,20}$ Menurut Branemark dkk (1985), durasi osseointegration pemasangan implan 2 tahap dari titanium murni sekitar antara $4-6$ bulan. Keadaan ini dipengaruhi oleh kecepatan proses regenerasi jaringan tulang periimplan. Selama menunggu proses osseointegration terjadi, umumnya penderita merasa kurang nyaman pada minggu pertama dan fungsi pengunyahan terganggu sebelum dipasang gigi tiruan di atasnya. ${ }^{21}$

\section{Material Implan Gigi}

Bahan implan yang ideal harus memiliki sifat biokompatibel, kuat menahan beban kunyah, tidak korosi, dan tahan terhadap fraktur. Prinsip-prinsip desain implan harus sesuai dengan sifat fisik material. Bahan yang digunakan untuk pembuatan implan gigi dapat dikategorikan menurut komposisi kimianya atau respons biologis yang didapatkan setelah dipasangkan. Berdasarkan komposisi kimia, implan gigi dapat dibuat dari logam, keramik atau polimer. ${ }^{13}$

Komposisi kimia ini dapat juga dibagi berdasarkan aktivitas biodinamik implan ketika material implan ditanamkan dan berinteraksi dengan jaringan tubuh dalam jangka panjang. Komposisi kimia material implan sesuai aktivitas biodinamik, terdiri dari implan biotolerant, implan bioinert, dan implan bioaktif, seperti terlihat pada tabel $1 .^{22}$ 
Tabel 1. Klasifikasi Material Implan di Kedokteran Gigi ${ }^{22}$

\begin{tabular}{|c|c|c|c|}
\hline \multirow{2}{*}{$\begin{array}{l}\text { Aktivitas } \\
\text { biodinamik }\end{array}$} & \multicolumn{3}{|c|}{ Komposisi kimia } \\
\hline & Logam & Keramik & Polimer \\
\hline \multirow[t]{6}{*}{ biotoleran } & Emas & & Polyethylene \\
\hline & Paduan cobalt & & Polyamide \\
\hline & chromium & & \\
\hline & Stainless steel & & Polymenthylmetacrylate \\
\hline & Zirkonium & & Polytetrafluoroethline \\
\hline & Tantaium & & Polyurethane \\
\hline \multirow[t]{3}{*}{ bioinert } & Titanium & Aluminium oksida & \\
\hline & murni & & \\
\hline & TI-6AI-4V & Zirkonium oksida & \\
\hline \multirow[t]{7}{*}{ bioaktif } & & Hidroksiapatit & \\
\hline & & Trikalsium fosfat & \\
\hline & & Brushite & \\
\hline & & Carbon-vitrous- & \\
\hline & & Pyrolitic & \\
\hline & & Carbon-silicon- & \\
\hline & & Bioglass & \\
\hline
\end{tabular}

Material biotoleran merupakan material yang tidak ditolak saat ditanamkan pada jaringan tulang, dan akan di kelilingi oleh jaringan lunak dan jaringan keras. Material implan yang ditanamkan akan menimbulkan respon dari tubuh dan tubuh akan menimbulkan respon terhadap bahan material. Material bioinert memungkinkan terjadinya aposisi permukaan tulang, yang mengarah pada terbentuknya osteogenesis. Dalam kondisi ini jaringan tubuh tidak bereaksi secara imunologi dengan adanya material implan, sehingga material tersebut dapat diterima oleh jaringan biologis dan proses osseointegrasi dapat terjadi. Material bioaktif memungkinkan terbentuknya tulang baru pada permukaan material karena adanya pertukaran ion dengan jaringan host sehingga terbentuk ikatan kimia osteogenesis. Kolagen dan mineral tulang akan berikatan langsung pada permukaan implan sehingga terjadi ikatan antara tulang dengan implan (Bone 
Implan Contact) ${ }^{23,24}$ Material bioiner dan bioaktif disebut juga material yang bersifat osteokonduktif, yang bertindak sebagai perancah (scaffold) untuk membentuk pertumbuhan tulang pada permukan implan. ${ }^{22,23,25}$

\section{Titanium}

Menurut American Society for Testing and Materials (ASTM), ada enam jenis titanium yang tersedia sebagai biomaterial implan. Di antara keenam bahan ini, ada empat grade titanium murni komersial atau commercial pure titanium (CpTi) dan dua titanium alloy (Ti). Sifat mekanik dan fisik CpTi berbeda dan terutama terkait dengan residu oksigen dalam logam. Kedua paduan tersebut adalah Ti-6Al-4V dan Ti-6Al-4V-ELI (paduan interstitial ekstra rendah). Bahan CpTi disebut titanium grade I, grade II, grade III dan grade IV murni. Titanium murni komersial juga disebut titanium tidak murni dan biasanya mengandung beberapa elemen karbon, oksigen, nitrogen, dan besi. Unsur-unsur ini secara nyata meningkatkan sifat mekanik titanium murni dan ditemukan dalam jumlah yang lebih tinggi dari grade I hingga grade IV. ${ }^{13,15,18,21}$

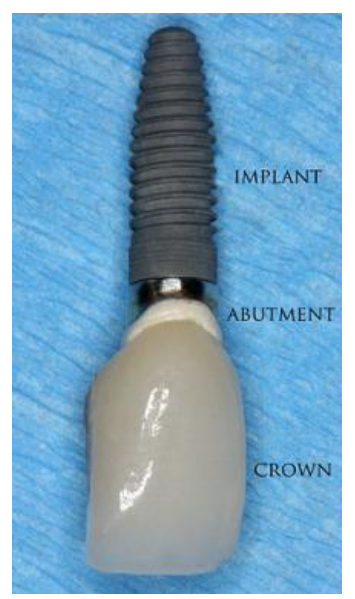

Gambar 1. Implan Gigi Titanium

Titanium dan paduan titanium merupakan bahan implan gigi yang paling umum digunakan, karena memiliki biokompatibilitas yang sangat baik. Tingkat keberhasilan dan kelangsungan jangka panjang yang tinggi telah dikonfirmasi dalam aplikasi yang berbeda di rongga mulut. ${ }^{12}$

Baru-baru ini ditemukan bahwa titanium dapat memberikan rasa tidak nyaman, kemungkinan hubungan antara korosi permukaan titanium dan reaksi hipersensitivitas, 
namun hanya sedikit bukti laporan kasus. Setelah kontak kulit atau mukosa, ion logam akan dilepaskan dari implan, yang kemudian membentuk kompleks dengan protein asli dan bertindak sebagai alergen, menyebabkan reaksi hipersensitivitas. ${ }^{13,15,16}$

Alergi terhadap titanium dalam literatur medis telah dijelaskan dalam bentuk urtikaria, pruritus kulit atau mukosa, dermatitis atopik, gangguan penyembuhan patah tulang dan nyeri, nekrosis dan melemahnya implan ortopedi. Penekanan kekebalan non-spesifik atau respons imun yang terlalu agresif juga telah dilaporkan sebagai bentuk alergi yang berbeda terhadap titanium, terutama yang sensitif. ${ }^{13,16,18}$

Dalam literatur gigi, alergi titanium telah dijelaskan dalam bentuk eksim wajah, dermatitis, ruam, gingiva hiperplastik edematosa non-keratin dan lepasnya implan, yang tidak dapat dikaitkan dengan infeksi, gangguan penyembuhan atau kelebihan. Singkatnya, reaksi alergi pada pasien dengan implan gigi titanium masih diperdebatkan. ${ }^{13,15,16}$

\section{Keramik}

Keramik pertama kali diperkenalkan ke implan gigi dalam bentuk pelapis metalbased endosseous untuk meningkatkan osseointegrasi. Selama 15 tahun terakhir, berbagai bentuk pelapis keramik telah digunakan pada implan gigi. Ini melibatkan pemanfaatan kedua bioactive ceramics, seperti kalsium fosfat dan bioglasses, dan inert ceramics, termasuk aluminium oksida dan zirkonium oksida. Pelapisan dapat padat atau berpori, dengan ketebalan mulai dari 1 hingga $100 \mu \mathrm{m}$, tergantung pada metode pelapis yang digunakan. Metode yang berbeda untuk melapisi implan logam, terdiri dari penyemprotan plasma, sputter-deposisi, lapisan sol-gel, deposisi elektroforesis atau presipitasi biomimetik. Bioaktif keramik telah terbukti melepaskan ion kalsium fosfat di sekitar implan, menghasilkan peningkatan apposisi tulang dibandingkan dengan permukaan keramik dan logam yang lebih lembam. Di antara yang paling banyak bahan pelapis kalsium fosfat yang populer adalah hidroksiapatit padat dan fluorapatit yang disemprot plasma. $8,9,12,27$

Dengan perkembangan ilmu biomaterial dan industri teknologi, minat penggunaan keramik sebagai bahan implan gigi semakin bertambah. Keramik, khususnya tetragonal polycrystalline zirconia (Y-TZP) yang distabilkan oleh yttrium, menunjukkan 
peningkatan sifat mekanik yang menjadikannya substrat yang cocok untuk pembuatan implan gigi. ${ }^{9,12,27}$

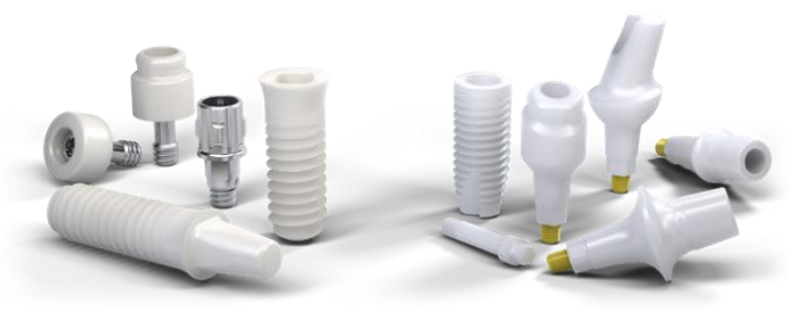

Gambar 2. Implan gigi berbahan keramik

Zirkonia merupakan logam yang bewarna putih keabuan dan sangat jarang ditemukan di alam bebas. Zirkonia banyak digunakan dalam industry high tech karena sifat mekanik, termal, elektrik, kimia dan optiknya yang mendukung. Zirkonia dikenal dengan zirconium oksida ( $\mathrm{ZrO} 2)$. Zirconia berasal dari unsur Zirconium $(\mathrm{Zr})$ yang memiliki nomor atom 40 dan masa atomnya sebesar 91,224. ${ }^{9,12,23}$ Zirconium oksida merupakan kristal berwarna putih keabu-abuan berbentuk amorf berupa struktur kristal yang tidak teratur, lunak, dapat ditempa dan diulur bila murni, juga tahan terhadap udara bahkan api. Penggunaan zirconia dalam kedokteran gigi antara lain, sebagai lapisan pelindung pada partikel pigmen titanium oksida, bahan tahan api, isolasi, abrasive dan enamel. Senyawa zirconium digunakan sebagai campuran dalam memaksimalkan gigi tiruan sehingga tidak terjadi fraktur dalam mulut. ${ }^{9,12,23}$ Zirkonia memiliki sifat fisis, mekanis, kimia dan biologis yang sangat cocok sehingga dipergunakan sebagai dental material. Pemilihan zirconium oksida dalam dental gigi tiruan bersifat biokompatibel, radiopasitas yang baik, resistensi terhadap faktur yang tinggi dan penyebaran partikel yang terjadi lebih baik dan tahan lama. $8,9,12,23$

Implan berbasis zirkonia dimasukkan ke dalam implantologi gigi sebagai alternatif dari implan titanium. Karena kemampuannya untuk dibentuk menjadi bentuk akar gigi alami dan ditempatkan segera setelah ekstraksi, karakteristik biomekanik yang sangat baik, biokompatibilitasnya, dan warna seperti gigi yang cerah, zirconia berpotensi menjadi pengganti titanium sebagai bahan implan. ${ }^{9,11,23,28}$ Dalam beberapa tahun terakhir, implan gigi zirkonia muncul sebagai alternatif untuk implan gigi titanium dan memberikan hasil estetika yang lebih baik. ${ }^{26}$ 
Zirkonia sebagai bahan implan gigi alternatif telah dilaporkan dengan baik dalam beberapa literatur. Penggunaannya dapat mencegah perubahan warna pada jaringan gingiva peri-implan, yang dalam banyak situasi dihubungkan dengan titanium implan, juga sifat zirkonia yang biokompatibilitas tinggi. Implan gigi zirkonia telah terbukti menunjukan penurunan tingkat plak dan lapisan biofilm dari permukaan implan. Hal ini berhubungan dengan berkurangnya pengeroposan tulang dan respon inflamasi dalam situasi dimana titanium akan menghasilkan peningkatan dalam situasi yang merusak, menyebabkan peningkatan peri-implantitis dan prematur kegagalan implan. Respon jaringan lunak di sekitar implan zirkonia lebih unggul dari yang di sekitar titanium. Prosedur penggantian tulang peri-implan dalam protokol invasif minimal, dengan penggabungan dari autologous fibrin yang kaya platelet dan Osseolive, bioaktive bonegraff materials, telah menghasilkan yang serupa penggantian tulang dengan prosedur yang sama sekitar implan titanium. . $9,30,31^{2}$

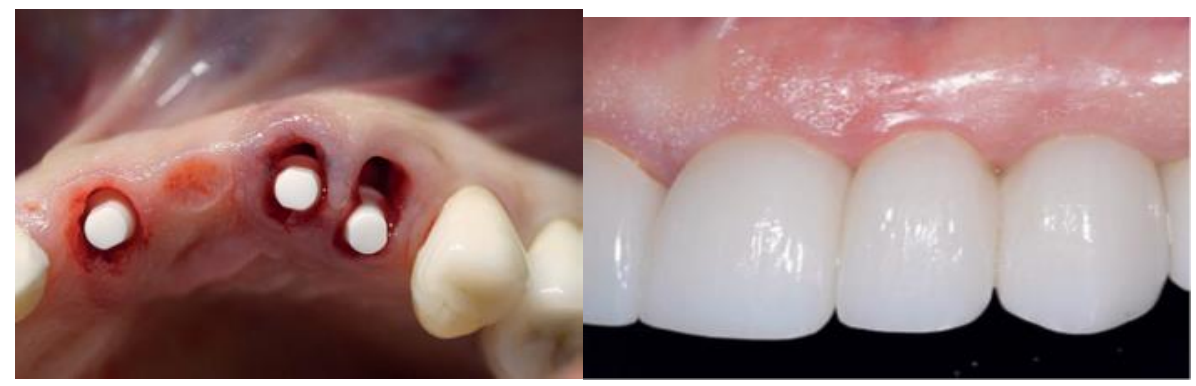

Gambar 3. Osseointegrasi dan soft tissue healing

Osseointegration dan Soft Tissue Healing dari bahan peleburan Zirkonia dan Titanium bersifat biokompatibel dan berintegrasi dengan baik dengan tulang dan gusi. Implan titanium dapat bertahan selama 20 tahun lebih sedangkan Zirkonia masih dalam penelitian karena belum digunakan cukup lama untuk dapat mengetahui kesuksesan jangka panjang. ${ }^{22,34,35}$

\section{PEMBAHASAN}

Di era modern saat ini penggunaan implan gigi sebagai pengganti gigi yang hilang sudah menjadi hal yang lumrah. Selain dapat mencegah penurunan tulang alveolar penggunaan implan gigi juga dapat menjaga keadaan gigi lainnya karena prosedur yang tidak membutuhkan preparasi atau pengurangan gigi sehat lainnya. Bahan implan yang 
ideal harus bersifat biokompatibel, kuat menahan beban kunyah, tidak korosi, dan ketahanan fraktur yang memadai. Bahan yang digunakan untuk pembuatan implan gigi dikategorikan menurut komposisi kimianya atau respon biologis yang mereka dapatkan ketika ditanamkan. Bahan yang umum digunakan sebagai bahan implan adalah titanium karena biokompatibilitasnya yang sangat baik, sifat mekanik yang menguntungkan. 3,7,31,32

Osseointegration adalah fiksasi biologis dari implan yang berhubungan langsung dengan kontak tulang ke implan (Bone Implant Contact) tanpa lapisan jaringan ikat yang mengintervensi. Bone Implant Contact (BIC) dianggap sebagai indikator kunci untuk keberhasilan osseointegrasi yang mengatur keberhasilan dan kelangsungan implan secara keseluruhan. Selain itu, sifat permukaan biomaterial memainkan peran mendasar dalam proses osseointegrasi. Komposisi bahan implan dan topografi permukaan mempengaruhi proses penyembuhan luka setelah implantasi dan selanjutnya mempengaruhi osseointegrasi. Topografi permukaan yang agak kasar diketahui secara positif mempengaruhi reaksi interfassial jaringan, oleh karena itu, banyak metode modifikasi permukaan implan gigi untuk meningkatkan osseointegrasi dan meningkatkan tingkat keberhasilan. Topografi permukaan mencakup optimalisasi kekasaran permukaan mikro (sandblasting atau etsa asam), aplikasi pelapis bioaktif (kalsium fosfat, bifosfonat, dan kolagen), partikel sintering ke permukaan implan, nanoteknologi, dan teknologi laser. $^{22,30,32,33,34}$ Meskipun banyak pembahasan tentang modifikasi dan struktur permukaan zirkonia, informasi yang tersedia tentang respon osseointegrasi dan interaksi tulang-implan dari implan ini masih jauh dari cukup. Dengan demikian, topografi permukaan yang optimal untuk implan gigi masih belum jelas. ${ }^{10,34,35}$

Komposisi bahan dan topografi permukaan suatu biomaterial memainkan peran mendasar dalam osseointegrasi. Menurut Albrektsson dkk, kualitas permukaan implan adalah salah satu faktor utama yang mempengaruhi penyembuhan luka di lokasi implantasi dan selanjutnya mempengaruhi osseointegrasi. Diketahui bahwa topografi permukaan, sifat kimia, dan kekasaran mempengaruhi laju dan kualitas pembentukan jaringan baru. Modifikasi permukaan dapat meningkatkan penyembuhan tulang dan integrasi implan titanium dan menghasilkan rasio kontak implan tulang yang lebih tinggi, namun interaksi antarmuka zirconia yang dimodifikasi dengan tulang masih belum sepenuhnya dipahami. ${ }^{34,35}$ 
Titanium dan paduan titanium merupakan bahan implan gigi yang paling umum digunakan, karena biokompatibilitas yang sangat baik. Namun, warna abu-abu dari titanium merusak estetika terutama pada kondisi mukosa tipis. Kondisi jaringan lunak yang tidak menguntungkan atau resisi gingiva dapat menyebabkan estetika terganggu. Ini menjadi perhatian besar ketika gigi seri rahang atas terlibat. Selain itu, laporan menunjukkan bahwa logam dapat menginduksi imunomodulasi dan autoimunitas yang tidak spesifik. Efek samping galvanik setelah kontak dengan saliva dan fluoride juga dijelaskan. Meskipun reaksi alergi terhadap titanium sangat jarang, sensitisasi seluler telah ditunjukkan. Dalam beberapa tahun terakhir, implan zirkonia telah muncul sebagai alternatif untuk implan titanium dan memberikan hasil estetika yang lebih baik. Meskipun telah ada banyak diskusi tentang modifikasi dan struktur permukaan zirkonia, informasi yang tersedia tentang respon osseointegrasi dan interaksi tulang-implan dari implan ini masih jauh dari cukup. Dengan demikian, topografi permukaan yang optimal untuk implan gigi masih belum jelas.

Selama beberapa dekade terakhir, desain implan gigi telah diperbarui dan ditingkatkan untuk menghasilkan proses osteointegrasi yang lebih cepat, pemeliharaan dan peningkatan level tulang estetika implan. Penelitian tentang hasil komplikasi yang didapat dari titanium sebagai basa logam untuk implan sehingga saat ini banyak dikembangkan dan diperkenalkan implan berbahan zirkonia. Implan zirkonia menawarkan estetika jaringan yang lebih baik menunjukan memiliki sedikit perlekatan plak dan pembentukan biofilm, karakteristik yang sangat penting dalam praktik klinis kedokteran gigi implan dalam program pemeliharaan jangka pendek dan jangka panjang. Penelitian lebih lanjut perlu dilakukan untuk lebih memvalidasi efektivitas zirkonia sebagai alternatif implan titanium di rongga mulut. ${ }^{6,19,27,29,31,32}$

Implan berbasis zirkonia dapat menjadi alternatif dari implan titanium karena memberikan hasil estetika yang lebih baik. Zirkonia memiliki ketahanan patah yang lebih tinggi daripada keramik yang tersedia sebelumnya, yang membuatnya kurang sensitif terhadap konsentrasi tegangan. Selain itu, berkat kekuatan kelenturnya yang tinggi, bagian tipis restorasi dapat dibuat tanpa risiko patah. Di sisi lain, zirkonia memiliki permukaan yang keras, padat, dan lembam secara kimiawi yang memastikan stabilitas kimianya dan kinerja jangka panjang di bawah kondisi lingkungan mulut yang keras. ${ }^{29,31,32}$ 
Zirkonia sebagai bahan implan alternatif telah didokumentasikan dengan baik dalam literatur gigi. Dalam laporan kasus menunjukkan setelah pasca penempatan implan dan restorasi akhir zirkonia terlihat kontur alami jaringan lunak dan keadaan gingiva yang sehat. Selain memperlihatkan estetika jaringan yang lebih baik, juga menunjukkan sedikit perlekatan plak dan pembentukan biofilm dari permukaan implan sehingga mucositis peri-implant dan peri-implantitis tidak berlanjut meningkat. ${ }^{22,35}$

\section{SIMPULAN}

Keberhasilan implan gigi tergantung terutama pada osseointegrasi implan ke dalam tulang host. Dibandingkan dengan implan logam titanium, implan zirconia kami juga memastikan penampilan estetika yang lebih baik, terutama pada gigi depan. Dimana titanium dapat meninggalkan garis gelap pada gusi, warna putih zirkonia menciptakan dasar yang ideal untuk penampilan yang alami.

\section{DAFTAR PUSTAKA}

1. Pedersen. Buku ajar praktis Bedah Mulut (Oral Surgery), Alih bahasa drg. Purwanto dan drg. Basoesemo, MS; editor, Lilian Yuwono, Jakarta; EGC; 1996.

2. Peterson LJ., Ellis E., Hupp JR., Tucker MR. Contemporary Oral and Maxillofacial Surgery, 4th ed, Mosby, Saint Louis ;2003.

3. Guéhennec., Soueidan., Layrolle., Amouriq. Surface treatments of titanium dental implants for rapid osseointegration, J. Dental Materials, 2007; 23: p. 844-854.

4. Albrektsson T., Wennerberg A. Oral Implant Surfaces : Review Focusing on Topographic and Chemical Properties of Different Surfaces and In vivo Responses to Them. Int. J. Prosthodont, 2004; 17: 536.

5. Elias., Oshida., Lima., Muller. Relationship between surface properties (roughness,wettability and morphology) of titanium and dental implant removal torque, J. Mechanical behavior of Biomedical Materials,2008 ;Vol. 1: p. 234-242.

6. Misch. Contemporary Implant Dentistry, Third Edition, Mosby Elsevier, St. Louis, Missouri ;2010.

7. Anusavice KJ. Philips Buku Ajar Ilmu Bahan Kedokteran Gigi, Alih bahasa : Johan Arief dan Susi Purwoko, Penerbit Buku Kedokteran EGC, Jakarta ;2004. 
8. Ozkurt $\mathrm{Z}$ and Kazazo glu E. Zirconia dental implants: a literature review, Journal of Oral Implantology, 2011; 37(3); 367-376.

9. Hisbergues H., Vendeville S., and Vendeville P. Review zirconia: established facts and perspectives for a biomaterial in dental implantology, Journal of Biomedical Materials Research—Part B Applied Biomaterials,2009; 88 (2): 519-529.

10. Regish KM., Sharma D and Prithviraj DR. An overview of immediate root analogue zirconia implants, Journal of Oral Implantology,2013;39(2): 225-233.

11. Aboushelib M.N., Salem NA., Taleb ALA and Moniem NMAE., Influence of surface nano-roughness on osseointegration of zirconia implants in rabbit femur heads using selective infiltration etching technique, Journal of Oral Implantology, 2013 ;39(5) : 583-590.

12. Cochran DL, Buser D, Bruggenkate CM, et al. The use of reduced healing times on ITI implants with a sandblasted and acid-etched (SLA) surface: Early results from clinical trials on ITI SLA implants. Clin Oral Implants Res ; 13:144-153; 2002.

13. Moskowitz EM, Sheridan JJ, Celenza FJr, Tovilo K, Munoz AM. Essix appliances. Provisional anterior prosthesis for pre- and post-implant patients. NY State Dent J ,1997;63: 32-35.

14. Massaro C., Rotolo P., Riccardis F.D., Milella E. Comparative Investigation of the Surface Properties of Commercial Titanium Dental Implants, Part I: Chemical Composition, J. Material in Med,2002; 13: 535-4.

15. Shabalovskaya SA. Surface, Corrosion and Biocompability Aspecst on Nitinol as an implants Material, J. Bio-Medical Materials and Engineering,2002; 12: 69-109.

16. Wohrle PS. Nobel Perfect esthetic scalloped implant: Rationale for a new design, Clin Implant Dent Relat Res,2003; 5(suppl 1):64-73.

17. Spriano S., Bronzoni M., Verne E., Maina G., Bergo V., Windle M, Characterization of Surface Modified Ti-6Al-7Nb Alloy, J. Material in Med,2005; 16: 301-12.

18. Powers., Sakaguchi. Craig's Restorative Dental Materials, Twelfth edition, Mosby Elsevier, St. Louis, Missouri;2006.

19. Simion M, Jovanovic SA, Tinti C, Benfenati SP. Long-term evaluation of osseointegrated implants inserted at the time or after vertical ridge augmentation. A retrospective study on 123 implants with 1-5 year follow- 
up, Clin Oral Implants Res; 12: 35-45;2001.

20. Jokstad. Osseointegration and Dental Implants, Edition first, Wiley-Blackwell ;2008.

21. Ionita and Iordachescu., , Improving Titanium Biocompatibility Manipulating Surface Porocity, NBC, Proceedings; 20: 19-22; 2008.

22. Sykaras N, Iacopino AM, Marker VA, Triplett RG, Woody RD. Implant Materials, Designs, and Surface Topographies: Their Effect on Osseointegration. A Literature Review. Int J Oral Maxillofac Implant,2000; 15(5): 675-90.

23. Yadav P, Tahir M, Shetty P, Saini V, Prajapati D. Implant design and stress distribution. Int J Oral Implant Clin Res,2016; 7(2): 34-9.

24. Bergmann C. Stumpf A. Dental Ceramics: Microstructure, Properties and Degradation. Berlin: Springer Science \& Business Media,2013; 84.

25. Jain R, Mittal R, Gyanchand, Gupta S. Implant surface designs: An overview. Ann Prosthodont Restor Dent,2016; 2(1): 17-20.

26. Jayaswal GP., Dange SP., and Khalikar AN. Bioceramic in dental implants: a review Tooth replacement with one-piece zirconia implants Laying the foundation for softtissue aesthetics, Journal of Indian Prosthodontist Society,2010; 10 (1): 8-12.

27. Paul S., USA ;2019.

28. Sagomonyants KB., Jarman-Smith ML., Devine J.N., Aronow MS., Gronowicz GA. The in vitro response of human osteoblasts to polyetheretherketone (PEEK) substrates compared to commercially pure titanium. Biomaterials, 24,3115-3123; 2007.

29. Magne P, Belser UC (eds). Bonded Porcelain Restorations in the Anterior Dentition: A Biomimetic Approach. Chicago: Quintessence; 2002.

30. Belser UC, Bernard JP, Buser D. Implant-supported restorations in the anterior region: Prosthetic considerations. Pract Periodontics Aesthet Dent ;8: 875-883; 1996

31. Hermann JS, Buser D, Schenk RK, Higginbottom FL, Cochran DL. Biologic width around titanium implants. A physiologically formed and stable dimension over time. Clin Oral Implants Res ;V.11:p.1-11,2000.

32. Raghoebar GM, Batenburg RH, Vissink A, Reintsema H. Augmentation of localized defects of the anterior maxillary ridge with autogenous bone before insertion of implants. J Oral Maxillofac Surg ,1996; 54:1180-1185. 
SONDE (Sound of Dentistry) Vol 5 No 2

33. Poernomo H., Pengaruh Lama Pencelupan Etsa $18 \% \mathrm{HCL}+49 \% \mathrm{H}_{2} \mathrm{SO}_{4}$ Terhadap Tingkat Kekasaran dan Wettability Permukaan Titanium Alloy, thesis, UGM Yogyakarta; 2011.

34. Wang HL, Carroll MJ. Guided bone regeneration using bone grafts and collagen membranes. Quintessence Int ,2001; 32:504-515.

35. Chin M. Distraction osteogenesis for dental implants. Atlas Oral Maxillofac Surg Clin North Am ; 7: 41-63, 1999. 